УДК: 37.016:004+37.091.12.046-021.68:004](07)

Гриценчук Олена Олександрівна

наукова співробітниця відділу компаративістики інформаційно-освітніх інновацій Інститут інформаційних технологій і засобів навчання НАПН України, м. Київ, Україна ORCID ID 0000-0003-3173-7649

helenekyiv2017@ukr.net

\title{
ЦИФРОВІ ОСВІТНІ ХАБИ ДЛЯ ПІДТРИМКИ ГРОМАДЯНСЬКОЇ ОСВІТИ ЯК СКЛАДОВА ІНФОРМАЦЙНО-ЦИФРОВОГО НАВЧАЛЬНОГО СЕРЕДОВИЩА: ДОСВІД НІДЕРЛАНДІВ, БЕЛЬГІЇ ТА УКРАЇНИ
}

\begin{abstract}
Анотація. У статті висвітлюється міжнародний та вітчизняний досвід впровадження цифрових освітніх хабів для підтримки громадянської освіти як елементу інформаційноцифрового навчального середовища. Проаналізовано основні поняття, розглянуто теоретичні підходи вітчизняних і зарубіжних дослідників та визначено роль цифрового освітнього хабу як сучасного інструменту інформаційно-цифрового навчального середовища. Обгрунтовано поняття «цифровий освітній хаб», що є багатофункціональним цифровим освітнім простором, де зібрано електронні освітні ресурси, навчальні матеріали, інструменти, технології; забезпечуються організаційно-педагогічні умови для набуття знань, формування та розвитку компетентностей учасників освітнього процесу, створено умови для ефективної та оперативної акумуляції інтелектуального потенціалу, що сприяє професійному та особистому самовдосконаленню, створенню інновацій та їх впровадженню в освіту. Опрацьовано вітчизняну законодавчу базу, що визначає актуальність громадянської освіти та потенціал цифрових освітніх хабів. На основі досвіду Нідерландів і Бельгії описано інструменти цифрових освітніх хабів, засобами яких реалізується громадянська освіта та її елементи в освітньому процесі закладів загальної середньої освіти. Здійснено аналіз сучасного стану впровадження освітніх хабів у вітчизняній освітній практиці та виявлено проблеми, що потребують грунтовного дослідження. Практичне значення цифрового освітнього хабу як складової інформаційно-цифрового навчального середовища полягає у сприянні створенню інновацій та їх упровадженню в освіту; реалізації проєктів; формуванні та розвитку особистості сучасного громадянина, що активно діє у цифровому середовищі. Новизна дослідження полягає в тому, що на основі узагальнення вітчизняного та зарубіжного досвіду надано рекомендації вітчизняним фахівцям щодо створення ресурсного цифрового освітнього хабу для підтримки громадянської освіти.
\end{abstract}

Ключові слова: інформаційно-цифрове навчальне середовище; інформаційні i комунікаційні технології; громадянська освіта; цифровий освітній хаб; освіта Нідерландів; освіта Бельгії; освіта України.

\section{1. ВСТУП}

Постановка проблеми та іï актуальність. Розвиток науки i технологій трансформує, розвиває й вдосконалює старі та створює нові форми організації життєдіяльності людини, оптимізуючи і осучаснюючи їх. Процеси інтеграції сфер суспільного життя, проблеми глобалізації впливають на трансформаційні зміни в освіті та вимагають залучення спільних зусиль та колективної роботи всіх освітян, що зумовлює оновлення підходів до організації процесів навчальної діяльності, визначаючи оновлення освітнього простору та розвиток сучасного освітнього середовища, що сьогодні характеризується технологічною насиченістю. Одним 3 елементів інформаційно-цифрового навчального середовища $є$ так званий цифровий освітній хаб. Засобами цифрових освітніх хабів може здійснюватись підтримка будьякої освітньої галузі, зокрема галузі громадянської освіти (ГО), потенціал якої 
забезпечує формування та розвиток однієї 3 ключових компетентностей громадянської.

Актуальність впровадження громадянської освіти та створення умов в освітньому середовищі для іiі реалізації відображені в останніх державних документах, а саме: Концепції розвитку громадянської освіти в Україні (2018р.), «що базується на необхідності створення сприятливих умов для формування та розвитку громадянських компетентностей людини на всіх рівнях освіти та в усіх складниках...» [1] та проєкті стратегії Громадянської освіти в Україні на період до 2022 року (2019р.), що передбачає формування і розвиток громадянської компетентності в закладах освіти за середовищним підходом[2]. Результати експериментальної перевірки моделі інформаційно-освітнього середовища як засобу розвитку громадянської компетентності вчителя, що проводилось у межах науково-дослідної роботи, виконаної в Інституті інформаційних технологій і засобів навчання НАПН України «Розвиток інформаційнокомунікаційної компетентності вчителя в умовах хмаро орієнтованого навчального середовища» (реєстраційний № 0117U000198), дозволили з'ясувати, що підвищення рівня розвиненості громадянської компетентності вчителів в умовах середовища, базованого на IKT, може бути досягнуто через створення організаційно-педагогічних умов та педагогічно доцільне та науково обгрунтоване застосування змісту, форм та засобів такого середовища в системі та при одночасному здійсненні громадянської освіти в навчально-виховному процесі в закладах загальної середньої освіти (33СО) [3].

Проблеми інтегрування інформаційно-комунікаційних технологій (IКТ) у процес навчання, здійснення освіти в умовах цифрового навчального середовища, інформаційно-комунікаційна компетентність (ІК-компетентність) учителя та ін. загострилась у зв'язку з введенням карантинних заходів, спрямованих на запобігання розповсюдженню вірусу COVID-19. Результати онлайн опитування, проведеного дослідниками Інституту інформаційних технологій і засобів навчання НАПН України щодо потреб учителів та інших категорій освітян у здійсненні дистанційного навчання та підвищенні фахового рівня під час запровадження карантину, пов'язаного 3 поширенням в Україні вірусу COVID-19 (квітень, 2020 р.), виявили ряд проблем та визначили необхідність розбудови цифрового навчального середовища, у якому створено організаційно-педагогічних умови для того, щоб учитель мав вільний доступ до електронних ресурсів, онлайн інструментів для розробки навчальних матеріалів, оцінювання, тестування, опитування, залучення до онлайн платформ для здійснення освіти, підвищення фахового рівня, комунікації та обміну досвідом у будь-який час і в будь-якому місці [4]. Цифровий освітній хаб може бути складником такого середовища.

Модернізація системи освіти в Україні останнім часом сприяла створенню різноманітних хабів. Так, у 2016 р. Міністерство освіти і науки України в рамках Концепції «Нової української школи» оприлюднило наміри створення мережі опорних шкіл, так званих освітніх хабів «Hub School» (англ. школа-хаб) у різних областях України з метою забезпечення рівного доступу та якості освіти, а також підняло питання ефективності використання ресурсів, зокрема інформаційно-цифрових [5]. Мережа створювалась із закладів загальної середньої освіти (33СО), оснащених сучасними лабораторіями та обладнанням, які мали виконувати роль опорних шкіл. Прийняття Закону про освіту 2017 р. стало правовою основою для цих шкіл. Станом на червень 2020 рокупо всій країні створено 912 шкіл-хабів (https://mon.gov.ua/ua/osvita/zagalna-serednya-osvita/oporni-shkoli). Цей проєкт досі знаходиться на стадії реалізації. На підтримку реформ у галузі освіти у 2017 р. Міністерство освіти і науки України представило Комунікаційну стратегію МОН 20172020, схвалену рішенням колегії МОН від 26.05.2017 № 4/1-15, де серед іншого йдеться про створення професійних хабів [6]. 
Виходячи 3 потреб сучасного громадянина, який живе та діє в цифровому середовищі та має швидко орієнтуватись у ньому, відповідально користуватись інформаційно-комунікаційними технологіями, проблема розвитку освітнього середовища, базованого на IКТ, та його складових, зокрема цифрових освітніх хабах, набуває актуальності і потребує дослідження. Упровадження цифрових освітніх хабів в Україні, зокрема тих, що спрямовані на здійснення ГО, дозволить сприяти впровадженню громадянської освіти та виховання, розвитку громадянської та IКкомпетентності учасників освітнього процесу, формуванню і розвитку громадянина. Надані рекомендації щодо створення та впровадження цифрового освітнього хабу для підтримки ГО сприятимуть удосконаленню процесу створення та розбудови сучасного інформаційно-цифрового навчального середовища засобами інтеграції цього сучасного цифрового інструменту в систему освіти.

Метою статті $\epsilon$ аналіз та узагальнення вітчизняного і зарубіжного досвіду 3 проблеми інтеграції цифрових освітніх хабів як елементу інформаційно-цифрового навчального середовища, з'ясування місця та ролі хабів у системі закладів загальної середньої освіти, уточнення змісту поняття «цифровий освітній хаб», надання рекомендацій щодо впровадження цифрових освітніх хабів 3 питань ГО в систему освіти України.

Аналіз останніх досліджень і публікацій. Концептуальні підходи до проблеми розвитку навчального середовища засобами IКT та теоретичні аспекти його формування розкривали у своїх працях В. Биков, В. Кремень [7], підкреслюючи роль педагогічної виваженості в процесі побудови такого середовища та місце, що в ньому посідають ІКТ. Обгрунтуванню теоретичних i методичних засад цифрової гуманістичної педагогіки присвячені дослідження В. Бикова, М. Жалдака та М. Лещенко [8]. Вчені наголошують на тому, що сучасні освітні процеси у фізичному та віртуальному просторі, де застосовуються ІКТ, $\epsilon$ поєднаними між собою. Фундаментальні та прикладні дослідження, присвячені проблемі розбудови інформаційно-цифрового навчального середовища, проводились вітчизняними та зарубіжними науковцями, а саме: проєктування та використання хмаро орієнтованого навчального середовища (С. Литвинова та М. Шишкіна) [8], технології використання мережних ресурсів в освітньому процесі та синтетичне навчальне середовище (О. Буров, С. Литвинова, О.Пінчук) [8, 9], формування вимог до електронного навчального середовища (А. Гуржій) [8], проблеми інформаційного суспільства та інформаційна роль освіти (В. Луговий, В. Олійник, О. Спірін) [8], розвиток комп'ютерно орієнтованого навчального середовища та особистий простір учня (Ю. Жук) [10], (Л. Карташова, В. Лапінський) [11]), розбудова хмаро орієнтованого персоналізованого освітнього середовища (Н. Морзе, С. Співак) [12], впровадження компетентісного підхіду та відкрита освіта в інформаційно-освітньому середовищі (О. Овчарук, О. Соколюк, А. Яцишин) $[9,13,14]$. Серед зарубіжних дослідників, роботи яких присвячені розвитку ІК-компетентності та моделюванню сучасного цифрового освітнього середовища П. Фіссер (P.Fisser), Дж. Воохт (J. Voogt), Дж. Тондер (J. Tondeur), Дж. Ван Браак (J. van Braak) [15] та ін.

Досвід зарубіжних країн щодо розвитку інформаційно-цифрового навчального середовища висвітлювали у своїх роботах М. Лещенко, О. Овчарук, І. Іванюк, О. Гриценчук, О. Кравчина, Н. Сороко, І. Малицька [13], [16], проблему навчального комп'ютерно орієнтованого середовища Щвеції розглядає у своїх дослідженнях I. Капустян [17], питання IKТ-зорієнтованісті змісту шкільної освіти в країнах Європейського Союзу відображені в працях О. Локшиної [18] та ін. Окремі аспекти проблеми розвитку громадянської освіти та освіти для демократичного громадянства в інформаційно-цифровому навчальному середовищі розглянуто в працях українських та 
зарубіжних науковців, а саме: розвиток комп'ютерно орієнтованого навчального середовища в умовах полікультурної освіти учнів у країнах Свропейського Союзу (I. Іванюк) [19], використання цифрових засобів навчання в професійній діяльності вчителів для забезпечення сталого розвитку та демократизації освіти в європейських країнах (О.В. Овчарук) [20], національно-патріотичне виховання в проєктній діяльності учнів на засадах використання хмарних сервісів та систем комп'ютерного моделювання (С.Г. Литвинова) [21], проблеми освітньої політики щодо демократичного громадянства в країнах Європи (Ц. Бірзеа (С. Birzéa) [22], педагогічні аспекти цифрового громадянства (M. Ріббле (M. Ribble), Дж. Байлей (G. Bailey), T.Pocc (T. Ross) [23], громадянська освіта в змісті освіти Нідерландів (Дж. Брон (J. Bron) [24] та iн.

Питання створення, впровадження і розвитку хабів як інноваційної складової освітнього простору висвітлено в працях українських та зарубіжних науковців, а саме: проблему створення хабу в процесі організації робочого простору в закладах вищої освіти висвітлено в публікаціях Н. Бондар, В. Губеня, І. Підтілок, Л. Шаран [25]; місце хабу в моделюванні процесів інтернаціоналізації вищої освіти досліджено О. Гринькевич і Н. Лутчин [26]; питання андрагогічної підготовки майбутніх викладачів та ролі освітніх хабів описані науковцем С. Ізбаш [27]; проблеми опорних шкіл (шкілхабів) досліджуються Н. Клокар [28]; ІКТ складова та особливості інноваційнотехнологічних хабів визначає Л. Федулова [29]; про інтернаціональні освітні хаби пише Дж. Найт (J. Knight) [30]; проблему школи як хабу освітнього і громадського простору досліджено в роботах (Д. Клєндфілд (D. Clandfield), Дж. Мартелл (G. Martell) [31] та ін. Однак питання створення, використання та розвитку цифрових освітніх хабів для підтримки громадянської освіти як елементу інформаційно-цифрового навчального середовища досліджено недостатньо.

\section{2. МЕТОДИКА ДОСЛІДЖЕННЯ}

Основні методи, що застосовані в дослідженні, - порівняльно-педагогічні методи співставлення явищ, аналіз науково-педагогічної літератури, нормативно-правових міжнародних та вітчизняних документів у галузі громадянської освіти та IКТ; дослідження та узагальнення підходів, моделей, педагогічного досвіду Нідерландів, Бельгії та України.

\section{3. РЕЗУЛЬТАТИ ДОСЛІДЖЕННЯ}

У сучасному інформаційно-цифровому навчальному середовищі важливу роль відіграє набуття життєво необхідних компетентностей, що забезпечать свідому й активну громадянську позицію та вільне використання ІКТ для реалізації ідеї цифрового громадянства, здатності до ефективної співпраці та комунікацій, навчання і розвитку протягом життя. Громадянська освіта та виховання - поняття багатогранні i багатовимірні. В українській педагогічній науці традиційно розрізняють поняття освіти і виховання, визнаючи, однак, їх єдність і нерозривність. Теж саме ми можемо сказати про громадянську освіту та громадянське виховання. Проблеми громадянської освіти висвітлюють у своїх роботах такі зарубіжні дослідники, як: Ц.Бірзеа, О.Ічілов, К.-Х. Дюрр, Р Голлоб, П. Крапф, В. Вайдінгер [22], [32] ін. - та українські педагоги, які активно працюють над впровадженням громадянської освіти в систему загальної середньої освіти, серед них - Вербицька П.В. (викладання історії в контексті громадянської освіти) [33], Сгоров Г.С. (досвід громадянознавства у Франції), Овчарук 
O.В. (освіта для демократичного громадянства та освіта в галузі прав людини) [16], Пометун O.І. (практичне право та освіта для демократії) [34], Тараненко І.Г. (тенденції та концептуальні підходи розвитку громадської освіти в Свропейських країнах) [35] та ін. Громадянська освіта, на думку вітчизняної дослідниці П. В. Вербицької, - це система навчально-виховних заходів, спрямованих на формування громадянськості як інтегративної якості особистості, котра усвідомлює свої права й обов'язки щодо суспільства й держави; залучення молоді до сприйняття демократичної системи цінностей; формування індивідуального досвіду активних і відповідальних дій у демократичному суспільстві [с.33]. У педагогічному словнику під редакцією С.У. Гончаренка подано таке визначення громадянського виховання: «Громадянське виховання - формування громадянськості як інтегративної якості особистості, яка дає можливість людині відчувати себе юридично, соціально, морально й політично дієздатною.» [36, с. 75]. На думку Ц.Бірзеа, громадянська освіта - це «освіта, що спрямована на виховання демократичного громадянства, $є$ комплексом практик і видів діяльності, спрямованих на покращення підготовки молодих людей i дорослих до активної участі в демократичному житті через реалізацію своїх прав і обов'язків у суспільстві» [22]. 3 вищеподаного $є$ очевидним, що різні визначення поняття громадянської освіти та виховання, подані вітчизняними та зарубіжними науковцями в різних інтерпретаціях, мають спільні риси та зберігають основний зміст та сутність.

Умови сучасного цифрового суспільства вимагають оновленого бачення та інноваційних підходів до організації діяльності людини. Такими інноваціями на початку 2000-х стали нові моделі організації професійної діяльності, зокрема хакерспейси (англ. hacker на слензі - досвідчений програміст чи користувач, англ. space - простір), коворкінги (англ. co-working - спільно працювати), що означає місце для спільної роботи, колективний офіс, та хаби. Поняття хаб (англ. $h u b$ ), що застосовується в транспортній галузі, сфері ІКТ, у переносному сенсі означає центр діяльності, уваги або центральний вузол мережі. У широкому сенсі сучасний хаб - це осередок, де зібрані різноманітні ресурси, здійснюється співпраця та спілкування, набувається досвід, проходять тренінги і навчання, акумулюються нові ідеї, реалізація яких потребує залучення i об'єднання однодумців, застосування ресурсів та інструментів, інтелектуальних напрацювань. Діяльність, що здійснюється в сучасному технологічно орієнтованому світі, відбувається як у реальному, так і у віртуальному просторі. За місцем розгортання хаб як продукт сучасного світу може бути: реальним, створеним на базі фізичного об'єкту (приміщення); віртуальним, що розміщується онлайн на спеціальних засобах (серверах); комбінованим, у якому поєднуються ознаки як реального, так і віртуального хабів. У вітчизняній освіті поняття «освітній хаб», «школа-хаб» (англ. hub-school) пов'язані 3 терміном «опорна школа», яке застосовується в Концепції нової української школи. Визначення поняття «опорна школа» було надано членами робочої групи, що здійснили в 2017 р. дослідження «Функціонування опорних шкіл»: опорна школа - це новий за формою організації та структурою загальноосвітній навчальний заклад, що є осередком єдиного освітнього простору, забезпечує рівний доступ до якісної освіти усім особам, має сучасний рівень матеріально-технічного й кадрового забезпечення» [37, с.3.].

Спираючись на узагальнений теоретичний підхід, науковець Л.І.Федулова зазначає, що хаб являє собою мережу партнерів, сприяє трансферу нових технологій, використовуючи можливості освітніх та наукових установ, їхню ресурсну базу та наукові досягнення. Дослідниця надає характеристику «інноваційно-технологічного хабу», що $\epsilon$ «новим етапом у комплексному використанні можливостей і ресурсів організацій, а також компаній для створення спільних продуктів і надання послуг через реалізацію проєктів з технологічною домінантою» [29, с. 12]. Досліджуючи проблему 
організації хабів у робочому просторі Н.П.Бондар, В.О.Губеня, І.С.Підтілок, Л.О.Шаран зазначають, що, крім робочих процесів, у хабі можуть проходити семінари, тренінги, творчі та музичні зустрічі, функціонувати бібліотека та буккросинг (англ. Bookcrossing - книгооберт) [25]. С.С. Ізбаш характеризує освітній хаб як місце реалізації інтерактивної форми роботи андрагогічної підготовки майбутніх викладачів [27]. Дослідниця Дж.Найт (J.Knight), яка досліджує проблему хабу як освітньої інновації в галузі вищої освіти, виділяє три різновиди хабів: студентський хаб, хаб талантів та хаб знань/інновацій [30]. Дослідниці О.С.Гринькевич та Н.П.Лутчин вважають освітній хаб інноваційною форм інституціоналізації процесів зближення, інтеграції національних освітніх систем та їх інститутів у глобальне освітнє середовище [26]. Отже, спираючись на зазначені вище думки дослідників, цифрровий освітній хаб можна охарактеризувати як багатофункиіональний компонент освітнього простору з IКТ складовою, створений з метою об'єднати та сконцентрувати циифрові освітні ресурси, інструменти, технології, де забезпечені організаційно-педагогічні умови для набуття знань, формування та розвитку компетентностей, реалізації співпрачі та спілкування учасників освітнього процесу (учнів, учителів, керівників навчальних закладів, студентів, аспірантів і докторантів, науковиів, батьків, громадських організачій та всіх зачікавлених осіб), організований з метою підтримки навчання $i$ виховання; вироблення ідей та обміну досвідом; набуття зв'язків з однодумиями та їх об'єднання, щуо сприяє створенню інновачій та їх впровадженню в освіту; реалізаціі проєктів; професійному та особистому саморозвитку та самовдосконаленню. Освітні хаби спрямовані на колаборацію у будь-якій освітній галузі, зокрема, громадянській освіті та вихованні. Це освітній простір, де $\epsilon$ можливість ефективно та оперативно акумулювати інтелектуальний потенціал для розв'язання нагальних проблем, обговорення гострих питань, що пов'язані з теоретичними та практичними аспектами громадянської освіти.

Досвід Нідерландів і Бельгії. Прикладом тематичного цифрового освітнього хабу $\epsilon$ нідерландський проєкт Клуб хабів «Цифрові календар-блоки» (https://www.digitalescheurkalender.com, м. Арнем, Нідерланди), що залучає до об'єднання та співпраці всіх зацікавлених учасників освітнього процесу: школи, музеї, бібліотеки, архіви та ін. На безкоштовній цифровій платформі хабу запропоновані інструменти для створення та використання навчальних матеріалів на смарт дошках $\mathrm{i}$ планшетах у вигляді календарів 3 певної тематики, що дозволяє членам клубу створювати власні цифрові календарі, ділитися напрацюваннями, використовувати ресурси інших хабів (Рис.1).

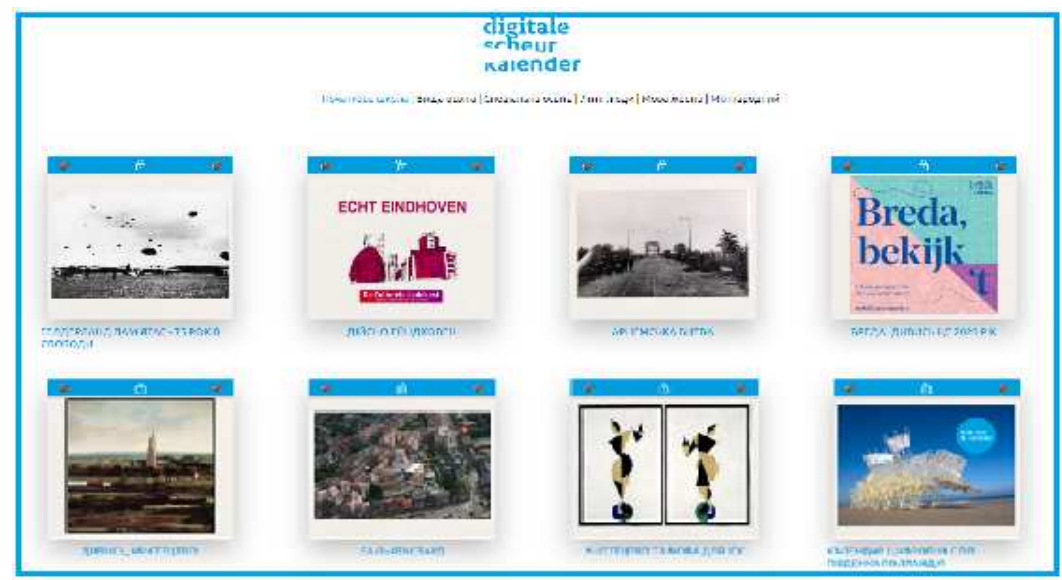

Рис. 1. Вебсторінка цииррового освітнього хабу «Цифрові календар-блоки», Нідерланди. (https://www.digitalescheurkalender.com) 
Більшість тем цифрових календарів, що можна застосовувати для навчання історії, географії, мовам, медіаграмотності, біології, технології містить теми 3 громадянської освіти та дотичні до неї, що запроваджується в Нідерландах наскрізно через усі предмети, наприклад, тематичні календарі «Історія скрізь», «Відкриття». «Гельдерландські спогади - 75 років свободи» та «Арнемська битва», присвячені подіям Другої світової війни та звільненню Нідерландів від фашизму. Про міста Нідерландів розповідають календарі «Ейндховен», «Валькенсвард», «Вид на Арнем», «Календар цифрових блоків Південна Голландія», «Бреда, перегляд 2019 року», що містять цікаві факти, пов'язані з певним містом Нідерландів та проілюстровані на фото тематичними блоками. Кожен блок може супроводжуватися змістовним текстом, датами подій, запитаннями для дискусій та обговорень, темами для досліджень.

Простір цифрового освітнього хабу може бути розбудований й інтегрований у цифрове освітне середовище закладу освіти (школи, методичного кабінету, закладу вищої освіти, закладу позашкільної освіти та ін.). Освітній цифровий хаб для підтримки ГО у школі «Люди та суспільство» створено в освітньому середовищі провідного фламандського видавництва «Die Keure» (https://www.diekeure.be/nlbe/educatief/secundair-onderwijs/hub), що бере активну участь у процесі розвитку освіти Бельгії (Рис.2).

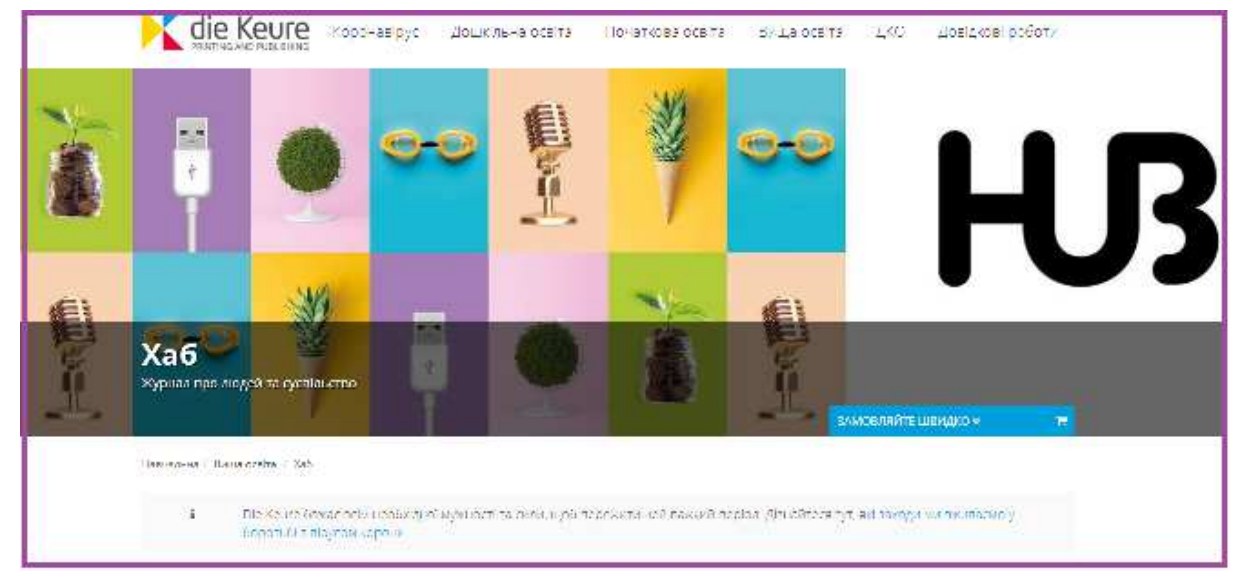

Рис. 2. Вебсторінка иифрового освітнього хабу «Люди та суспільство», Бельгія.(https://www.diekeure.be/nl-be/educatief/secundair-onderwijs/hub)

Функціонування цифрового освітнього хабу, що об’єднує католицькі школи Фландрії, спрямоване, зокрема, на такі важливі аспекти ГО, як формування та розвиток громадянської, комунікативної та IК-компетентностей, а також компетентностей, пов'язаних 3 фінансовою грамотністю, співпрацею тощо. Для викладання предмету «Людина і суспільство» у середній школі нідерландомовної частини Бельгії вчителю пропонується оригінальна методика, створена видавництвом на основі модульного методу. Для роботи з учнями запропоновано шість тематичних електронних журналів шість модулів, що можна використовувати в довільній послідовності. Теми електронних журналів містять елементи громадянської освіти, а саме: «Життя: харчування та здоров'я», «Назад до справи: підприємництво та благодійні організації», «Гра почалась: ігрові та соціальні медіа», «Пасаж: подорожі та природа», «Grinta: спорт» та «Острах публічного виступу: музика, кіно та театр». Використовуючи створену видавництвом освітню онлайн-платформу «POLPO» (www.polpo.be) учитель може скористатись ресурсами та інструментами для того, щоб створити власні навчальні розробки, застосувати диференційований підхід при викладанні, оцінити як учнів, так і себе. 
Освітній хаб може функціонувати як сам по собі, так і в складі мережі хабів. Мережа може бути розгорнута цілеспрямовано, також хаби можуть самі об'єднуватись у мережу, залучаючи до неї нових членів. Саме так утворилась Мережа хабів громадянського суспільства (Україна, https://www.hubs.org.ua). Як зазначають учасники Мережі, партнерські стосунки та співпраця посприяли ії створенню. Об'єднання хабів у мережу дозволяе координувати спільні дії, сприяе зміцненню організаційного потенціалу, допомагає об'єднати зусилля для реалізації ідей та проєктів, навчатися та обмінюватися досвідом. Прикладом системного підходу до організації процесу створення, впровадження та розвитку мережі цифрових освітніх хабів, що надають підтримку, зокрема, з громадянської освіти, може бути Національна мережа мультимедіа в освіті Нідерландів «Filmeducatie» (https:/www.filmeducatie.nl), яка в 2019 р. започаткувала проєкт створення Національної мережі мультимедійних хабів в освіті. Першими до проєкту приєднались східна провінція Гелдерланд, створивши хаб «FilmHUB Gelderland», та провінція південної Голландії з хабом «Beeldung». Проєкт набуває популярності - і мережа хабів розширюється. Так, у 2020 році до мережі долучилась ще одна східна провінція Оверейсел. Співпрацювати в хабах можуть учні, студенти педагогічних закладів вищої освіти, учителі та викладачі закладів вищої освіти, батьки, організації та установи освіти і культури та ін. Усі зацікавлені можуть здійснювати колаборацію, пропонуючи ідеї, залучаючись до проєктів, використовуючи ресурси, навчальні матеріали, відеоуроки та лекції, відвідуючи освітні і культурні заходи, шкільні вистави, музеї, бібліотеки та ін. Для вчителів цифрові освітні хаби пропонують курси підвищенні кваліфікації, на яких $є$ можливість дистанційно розвинути громадянську та ІК-компетентності, опанувати нові методи та форми роботи, навчитись застосовувати мультимедійні засоби та IКТ у професійній діяльності чи покращити їх. «Від критичних глядачів та медіа-творців - до творчих свідомих громадян» - теза, що демонструє місію хабу «FilmHUB Gelderland», а саме: формування здатного до аналізу, творчого, свідомого, відкритого, активного громадянина, спроможного критично ставитись до сучасних медіа. Ресурси, зібрані в хабі, можуть бути корисними для вчителів будь-якого предмету, зокрема тих, хто інтегрує знання з громадянської освіти у свій предмет. До 75-ї річниці вшанування кінця Другої світової війни, що відзначається в Нідерландах у 2020 році на національному рівні, для вчителів, які викладають громадянську освіту, та вчителів інших предметів, які іiі впроваджують на своїх уроках, у цифровому освітньому хабі «Beeldung» створено пакет уроків «75 років Свободи - війна і свобода в малюнках». Учителі можуть користуватись навчальними матеріалами, демонструвати фільми та обговорювати $з$ учнями тему війни, прав людини, демократичних цінностей та свобод. Концептуально побудова хабів Національної Мережі мультимедіа в освіті Нідерландів «Filmeducatie» витримується в єдиному ключі, що відображено на інтернет-сторінках: інтерактивна карта провінції розподілена на муніципалітети та містить інфографіку, що пропонує інформацію про актуальні події, що відбувається в галузі освіти кіно та медіа, пропозиції кінотеатрів, фестивалів, заходи в культурних центрах, бібліотеках, організаціях та установах провінції (Рис.3). 


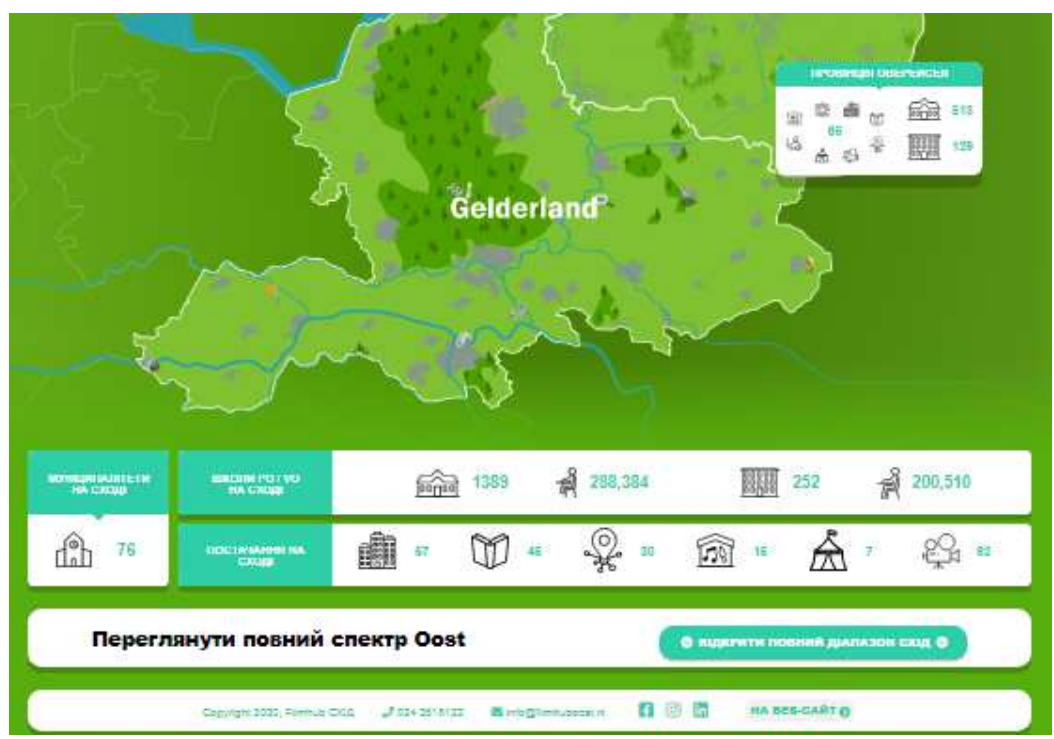

Рис. 3. Інтерактивна карта вебсторінки цииррових освітніх хабів Національної мережі «Filmeduсаtiе» з інфографікою, провіниї Гелдерланд та Оверейсл, Нідерланди,(http://www.filmeducatieoost.nl/).

Учитель для роботи з учнями може підібрати необхідні ресурси, використовуючи фільтри, які дозволяють здійснювати пошук за рівнем освіти: початкової, середньої та старшої; видом заходу; видом діяльності; а також знайти матеріали для роботи, курси підвищення фахового рівня у сфері медіаосвіти. У цифрових освітніх хабах збираються відомості про освітні платформи, координаційні центри культури та освіти, школи, що приєдналися до хабу, та ін. Викладачі, які долучились до роботи в хабі, розміщують свої вебсторінки, сторінки в соціальних мережах, блоги. Інтернет-сторінки хабів пропонують новини, цікаві факти, статті, видають бюлетені та багато іншого. Долучитись до хабу можна також через сторінки соціальних мереж Фейсбук (Facebook), Лінкдін (LinkedIn) та Інстаграм (Instagram).

Досвід України. Кількість вітчизняних освітніх хабів зростає з кожним роком. Серед них: «Освіторія Хаб», м. Київ (https://hub.osvitoria.org), «Spalah», мережа освітніх хабів (https://spalah.com.ua), хаб «Дивергент», м. Одеса (http://divergenthub.org), «HUB School», м. Вінниця (http://hubschool.com.ua), «World School Hub», мережа ліцензованих міжнародних шкіл в Україні (https://worldschool.com.ua), міжнародна мережа «Impact Hub», (https://impacthub.odessa.ua), «Довге хаб» с. Довге, Закарпаття, незалежна освітня корпорація «TеachHUB» (http://teach-hub.com), мережа «Kid`s hub» громадської організації «Кримська діаспора», «Education HUB», (http://edhub.com.ua) та багато інших. Потужним інструментом вітчизняного інформаційно-цифрового навчального середовище $\epsilon$ «Освітній Хаб міста Києва» (https://eduhub.in.ua), що має ресурсну базу, проводить навчання та тестування, тренінги 3 розвитку так званих м'яких навичок (англ. soft skills) та змішаного навчання, просуває освіту протягом життя. На теренах «Клубу видатних людей» «Освітнього Хабу міста Києва» проходять зустрічі з успішними та відомими українськими діячами з різних галузей, проводяться чемпіонати з інтелектуальних ігор, організовуються заходи з професійної орієнтації та багато іншого. Реалізація громадянської освіти здійснюється мережею «Learning Hubs», до якої залучено 40 шкіл Закарпатської, Донецької та Луганської областей. Одна із ініціатив, що запроваджуються мережею, освітній проєкт «Активні громадяни», що зібрав активну молодь 3 метою створення змін на місцях. Створюючи умови для взаємодії та співпраці вчителів, у хабі проводяться групи професійної майстерності. 
Багато хабів мають фізичну локацію (місцезнаходження), проте в більшості $є$ сторінка в мережі Інтернет, що має стрічку новин, висвітлює пропозиції та послуги хабу, містить посилання на сторінки хабу в соціальних мережах. Розвиток інформаційно-цифрової складової хабу є надзвичайно актуальною в умовах нагальної потреби здійснення дистанційного навчання. Організація на теренах хабу онлайн курсів, проведення вебінарів, електронного анкетування та тестування, групова співпраця на сучасних Інтернет-платформах може забезпечити всім зацікавленим вільний доступ до освіти незалежно від часу і місця їх знаходження, впроваджуючи освіту протягом життя.

До процесу створення хабів залучаються освітні заклади, що готують учителів і здійснюють підвищення їх кваліфікації. Так, Всеукраїнський освітній хаб педагогічних інновацій Нової української школи, створений на базі Черкаського обласного інституту післядипломної освіти педагогічних працівників Черкаської обласної ради у 2020 р., став базовим центром накопичення та розповсюдження авторських методик, технологій, моделей освітнього процесу та управлінської діяльності, інноваційних методів та форм роботи.

Прикладом упровадження ГО та іiі елементів може бути створений на базі Уманського державного педагогічного університету ім. П. Тичини у лютому 2020 р. «Skills Hub», де планується проведення майстер-класів та семінарів з розвитку «м'яких навичок»: учасники будуть опановувати навички командної роботи, учитись таймменеджменту (оптимальній організації часу для розв'язання поточних завдань) та розвивати ІК-компетентність. Учням і студентам запропонують навчатися створювати та робити виступи у форматі «TED-лекцій» («TED Talks») - проєкт некомерційної організації США «Конференція TED» («TED Conferences», абревіатура від англ. Technology, Entertainment Design - Технології, Розваги, Проєкти; www.ted.com), що 3 2006p. розповсюджує «ідеї, що змінять світ». Збірка аудіо- та відеофайлів кращих виступів, до якої є безкоштовний доступ, міститься в Інтернеті.

Упровадження наскрізної змістовної лінії ГО з 2017 року в програмах для 5-9 класів потребує організації підготовки вчителів, забезпечення їх якісними навчальними матеріалами і вільним до них доступом. Сьогодні існує небагато освітніх середовищ, які спрямовані на формування громадянської компетентності вчителів та учнів. Серед таких слід особливо відзначити вебмайданчик проєкту «Нова доба» Всеукраїнської Асоціації викладачів історії та суспільних дисциплін «3DДемократії» - «Майстерня громадянина» (https://citizen.in.ua/about.php) та освітню платформа “Живемо в демократіï” (http://www.living-democracy.com.ua).

Освітня платформа “Живемо в демократіï” (http://www.living-democracy.com.ua), започаткована в рамках швейцарсько-українського проєкту «Розвиток громадянських компетентностей в Україні - DOCCU» за сприяння Уряду Швейцарської конфедерації, пропонує ресурси Ради Європи 3 освіти для демократичного громадянства для проведення уроків та заходів на теми демократії, прав людини та громадянської участі (Рис.4).

На вебсторінках платформи розміщено навчальні матеріали, правові документи, відеоматеріали, ілюстровані картки про права дітей, ряд посібників Ради Європи в українському перекладі, серед яких «Навчаємо демократії», «Зростаємо в демократії», «Живемо в демократії», «Беремо участь в демократії», «Досліджуємо права дітей» та «Навчання демократії». Учні, батьки, учителі та керівники шкіл можуть знайти корисну для себе інформацію з питань ГО, навчатися, розвиватися та самовдосконалюватись. 


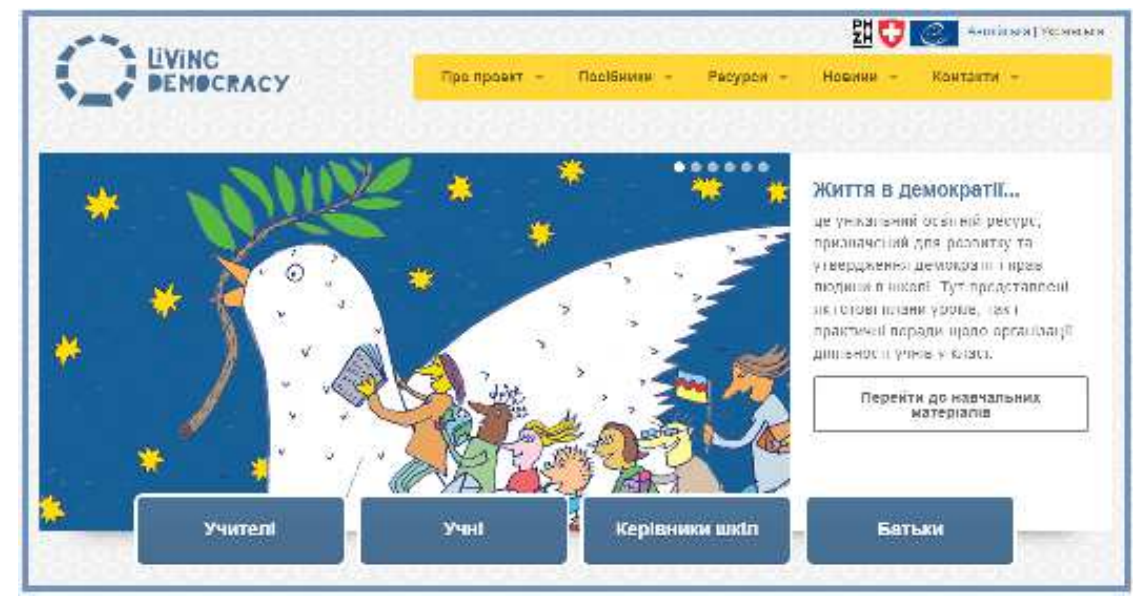

Рис.4. Вебсторінка освітньої платформи «Живемо в демократії» (https://www.living-democracy.com.ua/)

Ресурси, що розміщені на вебмайданчику проєкту «ЗDДемократії» «Майстерня громадянина», (https://citizen.in.ua/about.php), спрямовані на підтримку учнів та вчителів, які викладають громадянську освіту і можуть здійснювати різноманітну навчально-виховну діяльність онлайн.

На вебмайданчику для вчителів створено:

- учительська онлайн, що є спільнотою вчителів громадянської освіти;

- блок школи, де міститься інформація про заклад, що долучився до мережі, та його розташування на мапі України;

- журнал досягнень учнів класу, у якому фіксується активність кожного зареєстрованого учня, нараховуються певні бали в загальному «електронному класному журналі» по темах та розділах;

- актуальна інформація, де зібрано методичні матеріали, інформацію про актуальні вебінари, навчальні семінари, конференції для педагогів тощо.

«Майстерня громадянина» також пропонує інструменти та кроки для залучення до професійної онлайн спільноти (Рис.5).

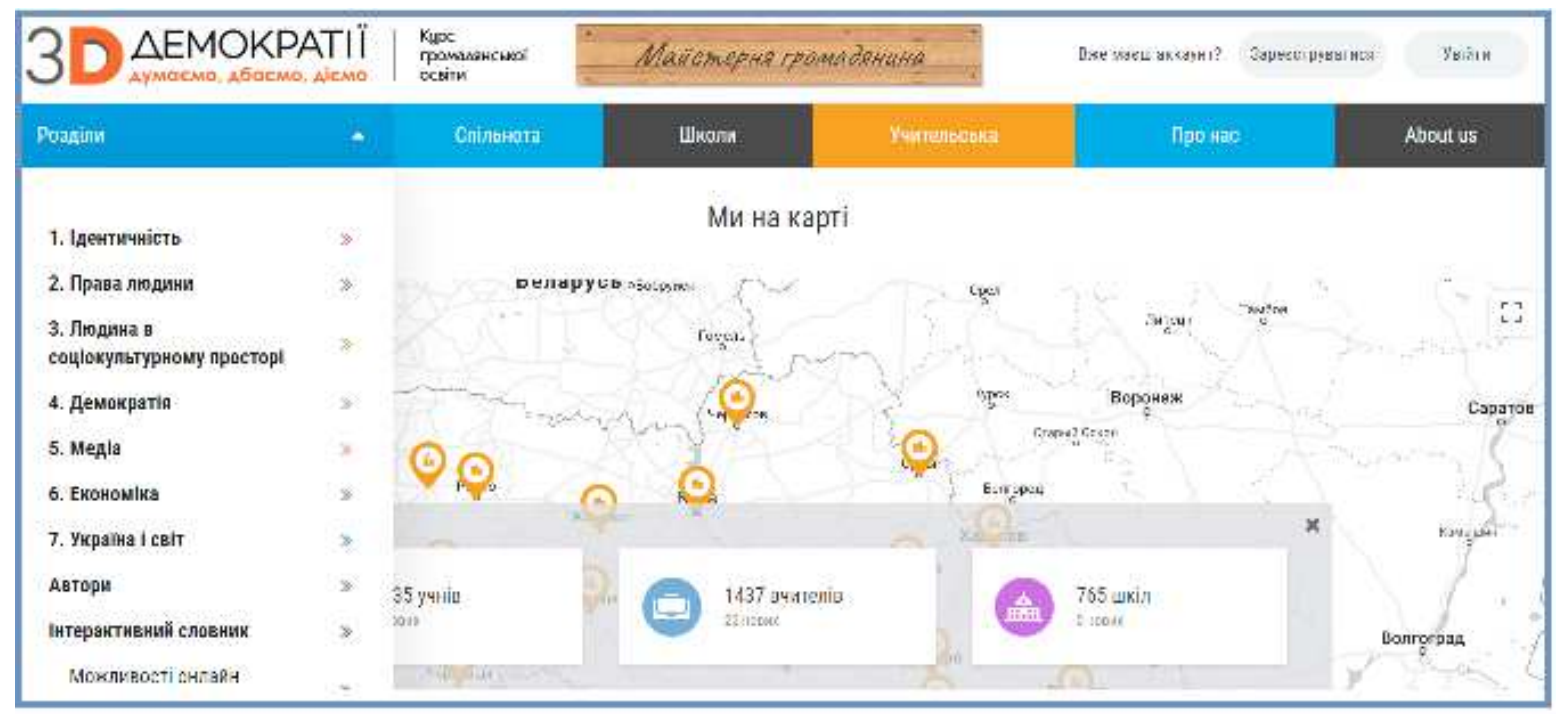

Рис.5. Інтернет сторінка веб-майданчику проекту «ЗДДемократії»(https://citizen.in.ua/about.php) 
Подані вище приклади вітчизняних проєктів, що використовують цифрові ресурси та інструменти і які розміщені на вебсторінках громадських організацій, використовують цікаві, інтерактивні посібники, методичні матеріали, завдання для учнів з різних тематик ГО (медіа, права людини, економіка, соціокультурний простір, культурне різноманіття, ідентичність та ін.), користуються широким попитом у вчителів. Так, на період серпня 2020 р. спільнота «3D Демократії» налічує 5035 користувачів, з яких близько 1500 - учителі. Такі показники свідчать про популярність та зацікавленість педагогів у ресурсній цифровій підтримці громадянської освіти.

Отже, базуючись на досвіді здійснення цифрової підтримки для громадянської освіти, наших спостереженнях за активністю педагогів у соціальних мережах, онлайн проєктах, викладених у цій статті, та враховуючи доступність та технологічні можливості ІКТ, варто привернути увагу педагогічної спільноти до зарубіжного та вітчизняного досвіду використання освітніх хабів (HUB). Ми пропонуємо створювати цифрові освітні хаби для підтримки громадянської освіти на базі закладів освіти, що можуть бути складниками інформаційно-цифрового навчального середовища.

Цифровий освітній хаб для підтримки громадянської освіти. Цифровий освітній хаб, як вже зазначалося, є середовищем для спільної освітньої діяльності. Сучасний стан розвитку IКТ пропонує широке розмаїття інструментів для того, щоб хаб був насиченим IКТ, що зробить доступ до нього відкритим та надасть можливість більш повно реалізувати його функції. Хаб може бути створений для окремого предмету, теми, проєкту чи освітньо-виховного напряму.

На рис. 6 представлено авторське бачення цифрового ресурсного хабу для підтримки ГО. Отже, цифровий ресурсний хаб з питань громадянської освіти може мати такі ресурси:

- посібники та методичні рекомендації з ГО;

- банк ідей та інновацій;

- онлайн мережі з ГО (вітчизняні та міжнародні);

- доступ до участі в проєктах з ГО;

- учнівські ініціативи та портфоліо з ГО;

- портфоліо вчителів, що викладають громадянську освіту чи впроваджують іiі елементи на своїх уроках;

- анкети, опитувальні листи, тестові завдання та інструменти моніторингу;

- платформи для спілкування та обміну досвідом серед колег, учнів, батьків.

Отже, ресурсний хаб з питань громадянської освіти може містити такі елементи:

конщептуальні та стратегічні документи з питань ГО: законодавчі документи та концепції у сфері загальної середньої освіти, освітні стандарти, стратегії щодо впровадження ГО в систему освіти України, міжнародні декларації та конвенції у сфері захисту прав людини, дотичні рекомендації Ради Свропи, ЮНЕСКО, ЮНІСЕФ, ООН та інших міжнародних структур з питань захисту прав людини та громадянської освіти;

посібники та методичні рекомендації з ГО (вітчизняні та міжнародні розробки 3 питань впровадження громадянської освіти, стандарти та рамкові підходи, навчальні програми та модулі з окремих тематик, наочність та посилання на законодавчу базу України щодо захисту прав людини та міжнародні документи, декларації та конвенції у сфері захисту прав людини);

онлайн мережі з ГО (вітчизняні та міжнародні): перелік та посилання на мережі, що пропонують інформаційні матеріали, навчальні ресурси для підвищення кваліфікації вчителів у сфері громадянської освіти, зокрема ті, що можуть бути використані безпосередньо в шкільній роботі. Важливо, щоб ці мережі були безпечними та містили професійну інформацію для вчителів та учнів; 


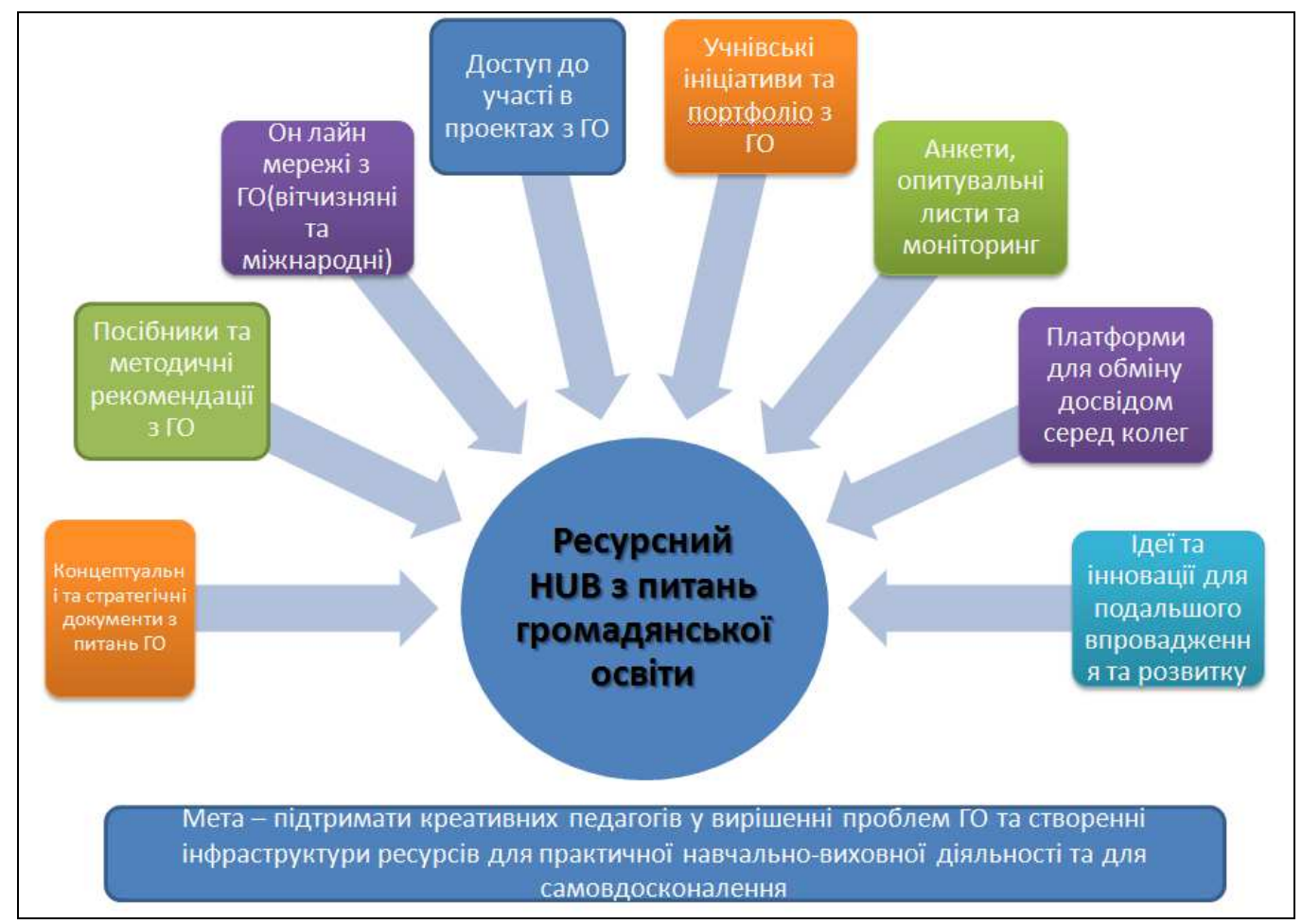

Рис.6. Цифровий ресурсний хаб для підтримки громадянської освіти

docmyn do yчacmi в проєктах з ГО: описи та посилання на проєкти 3 громадянської освіти, що здійснюються в Україні та зарубіжжі. Прикладом такого ресурсу може бути проєкт «Демократична школа», що здійснюється за підтримки Центру ім. Вергеланда (м.Осло, Норвегія), проєкт 3-D Демократія (Асоціація «Нова доба») та ін.;

учнівські ініціативи та портфоліо з ГО: опис учнівських досліджень, проєктів, приклади та результати конкурсних учнівських робіт, зокрема роботи, подані на тематичні олімпіади, творчі конкурси, фестивалі;

анкети, опитувальні листи та інструменти моніторингу: опитувальники, анкети та отримані дані, завдання, квести, тестові завдання та приклади;

платформи для обміну досвідом серед колег, учнів, батьків: посилання на професійні соціальні мережі (наприклад, мережі Фейсбук (Facebook), ЛінкдІн (LinkedIn), Інстаграм (Instagram)), вебсторінки, портали, платформи та ресурси для обміну досвідом, блоги, Ютуб (YouTube) канали, інші цифрові ресурси професійних спільнот з питань ГО;

ідеї та інноваџії для подальшого впровадження та розвитку: проєктні пропозиції, методичні розробки, сценарії проведення заходів з ГО;

електронні бібліотеки та депозитарій баз даних: лінки на бібліотеки, депозитарії, в тому числі державних установ, науково-дослідних організацій, музеїв, культурних центрів, громадських організацій (вітчизняних та міжнародних).

У ресурсному хабі на базі ІКТ має здійснюватись підтримка креативних педагогів у вирішенні проблем громадянської освіти та створенні інфраструктури для практичної навчально-виховної діяльності, умов для підвищення кваліфікації та самовдосконалення. Важливо також враховувати можливості громадських організацій, що пропонують програми з громадянської освіти, та проєкти. 
Технічна підтримка та організація інформаційно-цифрового навчального середовища для впровадження ГО має містити: комплекс послуг, спрямованих на забезпечення надійного, безпечного та захищеного функціонування обладнання та сервісів мережевої, обчислювальної та інженерної інфраструктури середовища.

\section{4. ВИСНОВКИ ТА ПЕРСПЕКТИВИ ПОДАЛЬШИХ ДОСЛІДЖЕНЬ}

Провівши аналіз вітчизняного та зарубіжного досвіду щодо проблеми цифрових освітніх хабів, можна зробити певні висновки та надати такі рекомендації:

1. Пропонуючи авторське бачення цифрового ресурсного хабу для підтримки громадянської освіти, варто звернути увагу на такі рекомендації щодо його складових, як: банк ідеї та інновацій для подальшого їх впровадження в навчально-виховний процес, цифрові платформи для здійснення комунікацій та інструменти для оцінювання та анкетування; сторінки хабу в соціальних мережах, блоги та сайти вчителів, що проводять навчання, семінари, лекції, воркшопи.

2. Організаційно цифровий освітній хаб може бути створеним на базі закладу загальної середньої освіти, закладу позашкільної освіти, установи, що здійснює післядипломну освіту, громадської організації, науково-дослідної установи, існуючих методичних кабінетів та об'єднань.

3. Важливим є забезпечення засобами цифрового освітнього хабу вільного доступ та налагодження організації дистанційного навчання і можливості долучатись до освітнього процесу всім зацікавленим незалежно від місця їх знаходження i часу.

4. Функціонування цифрового освітнього хабу має бути орієнтоване на розвиток громадянської компетентності та водночас ІК-компетентності через інтегрування елементів онлайн навчання та використання цифрових засобів для поширення громадянської освіти та розбудови громадянського суспільства.

5. Цифровий освітній хаб 3 питань громадянської освіти $\epsilon$ елементом інформаційно-цифрового навчального середовища, що осучаснює та підсилює його, забезпечуючи розвиток громадянської та IК-компетентності учасників навчально-виховного процесу; засобами цифрових освітніх хабів можуть бути створені тематичні, галузеві, предметні та інші навчальні середовища; створення мережі цифрових освітніх хабів з питань громадянської освіти посприяє розвитку освіти взагалі, формуванню громадянина та розбудові громадянського суспільства, побудованого на засадах демократії.

6. Цифровий освітній хаб з питань громадянської освіти, де вчитель має вільний доступ до електронних ресурсів, онлайн інструментів для розробки навчальних матеріалів, оцінювання, тестування, опитування, залучення до онлайн платформ для здійснення освіти, підвищення фахового рівня, комунікації та обміну досвідом у будь-який час і будь-якому місці, може посприяти розв'язанню проблем, що загострились у зв'язку 3 введенням карантинних заходів, спрямованих на запобігання розповсюдженню вірусу COVID-19.

Проведене дослідження не вичерпує розв'язання всього спектру питань, пов'язаних зі створенням і розвитком цифрових освітніх хабів 3 питань ГО. Наукові розвідки доцільно продовжувати в напрямах дослідження ефективності функціонування цифрових освітніх хабів для підтримки ГО, шляхів розбудови мережі таких хабів у вітчизняному освітньому просторі, забезпечення їх науково-методичної підтримки, аналізу і розвитку інструментарію цифрових освітніх хабів. 


\section{СПИСОК ВИКОРИСТАНИХ ДЖЕРЕЛ}

[1]. Кабінет Міністрів України. (2018, жовтень 3). Розпорядження № 710-р, Про схвалення Концепиії розвитку громадянської освіти в Украӥни. [Електронний ресурс]. Доступно: https://zakon.rada.gov.ua/laws/show/710-2018-\%D1\%80\#n10.

[2]. МОН України. (2019, березень 27). Стратегія розвитку громадянської освіти на період до 2022. Проєкт. [Електронний ресурс]. Доступно: https://mon.gov.ua/ua/news/mon-proponuye-dlyagromadskogo-obgovorennya-strategiyu-rozvitku-gromadyanskoyi-osviti-na-period-do-2022-roku.

[3]. О.О. Гриценчук, “Експериментальна перевірка ефективності моделі інформаційно-освітнього середовища як засобу розвитку громадянської компетентності вчителів”, Комп'ютер у школі та сім'ї, № 1. стор. 15-18.

[4]. І..В. Іванюк, та О.В. Овчарук, “Результати онлайн опитування щодо потреб вчителів у підвищенні фахового рівня 3 питань використання цифрових засобів та ІКТ в умовах карантину“. Інститут інформаційних технологій i засобів навчання НАПН України, м. Київ, Україна, 2020. [Електронний ресурс]. Доступно: https://lib.iitta.gov.ua/719908/

[5]. МОН України. Нова украӥнська школа. Концепиія. [Електронний ресурс]. Доступно: http://mon.gov.ua/activity/education/zagalna-serednya/ua-sch-2016/.

[6]. МОН України. Комунікаџійна стратегія МОН 2017-2020. (2017, травень 26) № 4/1-15. [Електронний ресурс]. Доступно: https://mon.gov.ua/storage/app/media/komunikaczijna-strategiyamon-2017-2020.pdf.

[7]. В.Ю. Биков, та В.Г. Кремень, "Категорії простір і середовище: особливості модельного подання та освітнього застосування “, Теорія $і$ практика управління сочіальними системами: філософія, психологія, педагогіка, соиіологія, №2, с. 3-16, 2003.

[8]. В.Ю. Биков, та ін. Теоретико-методологічні засади інформатизаиії освіти та практична реалізація інформаційно-комунікаційних технологій в освітній сфері Украӥни, Монографія, Компринт, м. Київ, Україна, 2019.

[9]. В.Ю. Биков, та ін. Формування інформаційно-освітнього середовища навчання стариокласників на основі технологій електронних соиіальних мереж, Монографія, Педагогічна думка, м. Київ, Україна, 2018.

[10]. Ю.О. Жук, “Особистісний простір учня в комп’ютерно-орієнтованому навчальному середовищі”, Інформаційні технології $i$ засоби навчання, т. 29, №3, 2012. [Електронний ресурс]. Доступно: http://journal.iitta.gov.ua/index.php/itlt/article/view/693/508.

[11]. А.М. Гуржій, В. В. Лапінський, та Л.А. Карташова, Електронні освітні ресурси як суспільне явище, "Сучасні інформаційні технологї та інноваційні методики навчання в підготовиі фахівиів: методологія, теорія, досвід, проблеми”, № 44, с. 14-22, 2016.

[12]. Н.В. Морзе, та С.М. Співак, “Формування сучасного хмаро орієнтованого персоналізованого освітнього середовища враховуючи ікт-компетентність учасників навчального процесу “, Відкрите освітнє е-середовище сучасного університету, №3, с.274-282, 2017. doi: 10.28925/24140325.

[13]. О.В. Овчарук та ін., Розвиток інформаційно-комунікаиійної компетентності вчителів в умовах хмаро орієнтованого навчального середовища: методичний посібник. Київ, Україна: Літера ЛТД, 2019.

[14]. А.В. Яцишин, та ін., Цифрова трансформачія відкритих освітніх середовищ. Монографія. Київ, Україна: ФОП О.В. Ямчинський, 2019.

[15]. P. Fisser, J. Voogt, J. Tondeur, and J. van Braak, “TPACK: kennis en vaardigheden voor ICTintegratie”, Weten Wat Werkt en Waarom”, Kennisnet. Zoetermeer, vol. 2, no. 2, pp. 22-29, juni 2013. [Електронний peсурс]. Доступно: https://www.kennisnet.nl/app/uploads/kennisnet/publicatie/4w/4w_magazine_20132.pdf .

[16]. O. Ovcharuk, I. Ivaniuk, N. Soroko, O. Gritsenchuk, and O. Kravchyna , "The use of digital learning tools in the teachers' professional activities to ensure sustainable development and democratization of education in European countries", in E3S Web of Conferences, 166 (10019), 2020. [Електронний pecypc]. Доступно: https://www.e3sconferences.org/articles/e3sconf/abs/2020/26/e3sconf_icsf2020_10019/e3sconf_icsf2020_10019.html.

[17]. I.I. Капустян, “Розвиток навчального комп’ютерно орієнтованого середовища у неперервній педагогічній освіті Швеції”, автореферат канд. дис., ІІТЗН НАПН України, Київ, 2012. [Електронний ресурс]. Доступно: https://lib.iitta.gov.ua/1086/.

[18]. O.І. Локшина, "ІКТ-зорієнтованість змісту шкільної освіти в країнах Європейського Союзу”, Інформаціийні технології $i$ засоби навчання, т. 45, №1, 2015. [Електронний ресурс]. Доступно: https://lib.iitta.gov.ua/714420/. 
[19]. І.В. Іванюк, “Розвиток комп’ютерно орієнтованого навчального середовища в умовах полікультурної освіти учнів в країнах Європейського Союзу”, автореферат канд. дис., IITЗН НАПН України, Київ, Україна, 2016. [Електронний ресурс]. Доступно: https://lib.iitta.gov.ua/166249/.

[20]. О.В. Овчарук, “Сучасні підходи до розвитку цифрової компетентності людини та цифрового громадянства в європейських країнах”, Інформаційні технологї̈ $і$ засоби навчання, т. 76, №2, с. 113, 2020. [Електронний ресурс]. Доступно: https://lib.iitta.gov.ua/720330/.

[21]. С.Г. Литвинова, "Національно-патріотичне виховання в проектній діяльності учнів на засадах використання хмарних сервісів та систем комп'ютерного моделювання (СКМОД)”, Педагогічний часопис Волині, т.8, №1, с. 72-82, 2018. doi:10.29038/2415-8143.

[22]. C. Birzéa et al. , All-European Study on Education for Democratic Citizenship Policies. Strasbourg, France: Council of Europe Publishing, 2004. [Електронний ресурс]. Доступно: https://rm.coe.int/16802f7040.

[23]. M. Ribble, G. Bailey, and T. Ross. "Digital Citizenship: Addressing Appropriate Technology Behavior", Learning \& Leading with Technology, vol. 32, no.1, pp. 6-9, Sep. 2004. [Електронний ресурс]. Доступно: https://eric.ed.gov/?id=EJ695788.

[24]. J. Bron, and E. van Vliet. "Democracy, participation and identity A curriculum proposal for Dutch education”, Teaching Citizenship, vol.34, pp. 32-35. 2012. [Електронний ресурс]. Доступно: https://issuu.com/openshaw/docs/actjournal34.

[25]. Н.П. Бондар, Л.О. Шаран, В.О. Губеня, та І.С. Підтілок, “Упровадження інноваційних способів організації робочого простору у закладах готельного господарства”, Молодий вчений, № 1 (65), с. 423-427, 2019. doi: 10.32839/2304-5809/2019-1-65-98.

[26]. О.С. Гринькевич, та Н.П. Лутчин, Аналіз і моделювання процесів інтернаціоналізації вищої освіти у контексті інноваційного розвитку. Маркетинг $і$ менеджмент інновацій, № 3, с. 314-325, 2017. Doi: $10.21272 / \mathrm{mmi} .2017 .3-29$.

[27]. С.С. Ізбаш, “Реалізація принципу здоров'язбереження у процесі андрагогічної підготовки майбутніх викладачів”, на VII Всеукр. наук.-практ. конф. Педагогіка здоров'я, Чернігів, 7-8 квіт. 2017 p., т.1., c. $270-274$.

[28]. Н.І. Клокар, “Опорна школа як центр освітнього кластеру”, у Актуальні питання, проблеми та перспективи розвитку гуманітарного знання у сучасному інформаційному просторі: національний та інтернаціональний аспекти: збірник наукових праць, Ред. М.А. Журба, Монреаль, Канада: $\mathrm{CPM} \ll \mathrm{ASF} », 2018$, c.63-65.

[29]. Л.І. Федулова, “Інноваційно-технологічні хаби - драйвери розвитку регіонів” у Економічна теорія та право: збірник наукових праць, №1 (24), с. 11-27, 2016.

[30]. J. Knight, International Education Hubs: Student, Talent, Knowledge Models. Journal of Higher Education Policy and Management, 2014, vol 36, no. 3, pp. 355-365.

[31]. D. Clandfield, "The School as Community Hub a Public Alternative to the Neo-Liberal Threat to Ontario Schools", Our Schools/Our Selves, Ottawa, Canada. 2010, vol.19, no. 4, issue 100, pp. 5-74. [Електронний ресурс]. Доступн: https://www.policyalternatives.ca/sites/default/files/uploads/publications/ourselves/docs/OSOS_Summer1 0_Preview.pdf.

[32]. O.Ichilov, Patterns of Citizenship in a Changing World. In: O. Ichilov (ed.) Citizenship and Citizenship Education in a Changing World, The Woburn Press, London, 1998, pp.11-27.

[33]. В.П. Вербицька, “Теоретико-методичні основи громадянського виховання учнівської молоді у загальноосвітніх навчальних закладах", дис. д-ра пед. наук, Ін-т проблем виховання АПН України, Київ, Україна, 2010.

[34]. О. Пометун, Т. Ремех, та Л. Пилипчатіна, Правознавство. Практичний курс: методичний посібник для вчителів. Київ, Україна, Логос, 2009.

[35]. І.Г. Тараненко, “Демократичні цінності у становленні громадянина”, Педагогіка і психологія, № 2, c. 28-35, 1997.

[36]. Український педагогічний словник , С. У. Гончаренко, гол. ред. С. Головко. Київ: Либідь, 1997.

[37]. Функціонування опорних шкіл за результатами опитування директорів опорних шкіл. Інститут освітньої аналітики МОН України, 2017 р. [Електронний ресурс]. Доступно: https://iea.gov.ua/wpcontent/uploads/2017/12/1.pdf . 


\title{
ЦИФРОВЫЕ ОБРАЗОВАТЕЛЬНЫЕ ХАБЫ ДЛЯ ПОДДЕРЖКИ ГРАЖДАНСКОГО ОБРАЗОВАНИЯ КАК СОСТАВЛЯЮЩАЯ ИНФОРМАЦИОННО-ЦИФРОВОЙ УЧЕБНОГО СРЕДЫ: ОПЫТ НИДЕРЛАНДОВ, БЕЛЬГИИ И УКРАИНЫ
}

\section{Гриценчук Елена Александровна}

научный сотрудник отдела компаративистики информационно-образовательных инноваций Институт информационных технологий и средств обучения НАПН Украины, г. Киев, Украина ORCID ID 0000-0003-3173-7649

helenakyiv2017@ukr.net

\begin{abstract}
Аннотация. В статье освещается международный и отечественный опыт внедрения цифровых образовательных хабов для поддержки гражданского образования как элемента информационно-цифровой учебной среды. Проанализированы основные понятия, рассмотрены теоретические подходы отечественных и зарубежных исследователей и определена роль цифрового образовательного хаба как современного инструмента информационно-цифровой учебной среды. Обосновано понятие «цифровой образовательный хаб», что является многофункциональным цифровым образовательным пространством, где собраны электронные образовательные ресурсы, учебные материалы, инструменты, технологии; обеспечиваются организационно-педагогические условия для приобретения знаний, формирования и развития компетентностей участников образовательного процесса, созданы условия для эффективной и оперативной аккумуляции интеллектуального потенциала, профессионального и личного совершенствования, создания инноваций и их внедрения в образование. Обработано отечественную законодательную базу, которая определяет актуальность гражданского образования и потенциал цифровых образовательных хабов. На основе опыта Нидерландов и Бельгии описаны инструменты цифровых образовательных хабов, средствами которых реализуется гражданское образование и его элементы в образовательном процессе учреждений общего среднего образования. Осуществлен анализ современного состояния внедрения образовательных хабов в отечественную образовательную практику и выявлены проблемы, требующие основательного исследования. Практическое значение цифрового образовательного хаба как составляющей информационно-цифровой учебной среды заключается в содействии создания инноваций и их внедрению в образование; реализации проектов; формировании и развитии личности современного гражданина, который активно действует в цифровой среде. Новизна исследования заключается в том, что на основе обобщения отечественного и зарубежного опыта даны рекомендации отечественным специалистам по созданию ресурсного цифрового образовательного хаба для поддержки гражданского образования.
\end{abstract}

Ключевые слова: информационно-цифровая учебная среда; информационные и коммуникационные технологии; гражданское образование; цифровой образовательный хаб; образование Нидерландов; образование Бельгии; образование Украины.

\section{DIGITAL EDUCATIONAL HUBS FOR CIVIC EDUCATION AS A COMPONENT OF THE INFORMATION AND DIGITAL LEARNING ENVIRONMENT: EXPERIENCE OF THE NETHERLANDS, BELGIUM AND UKRAINE}

Olena O. Hrytsenchuk

researcher of the Comparative Studies Department for Information and Education Innovations Institute of Information Technologies and Learning Tools of the NAPS of Ukraine, Kyiv, Ukraine ORCID ID 0000-0003-3173-7649

helenekyiv2017@ukr.net

Abstract. The article covers the international and domestic experience of implementation of digital educational hubs for supporting civic education as an element of information and digital learning environment. The basic concepts and theoretical approaches of domestic and foreign 
researchers are analysed and the role of digital educational hub as a modern tool of information and digital learning environment is determined. The concept of "digital educational hub" is substantiated, which is a multifunctional digital educational space, where educational resources, tools, technologies are concentrated; the organizational and pedagogical conditions for the acquisition of knowledge, formation and development of competencies of participants in the educational process are provided; the conditions for effective and efficient accumulation of intellectual potential to solve urgent problems are created; the issues of education and upbringing can be discussed. This promotes professional and personal self-improvement of pedagogues, as well as innovation implementation into practice. The domestic legal framework is analysed; it determines the relevance of civic education and the potential of digital educational hubs. Based on the experience of the Netherlands, Belgium and Ukraine digital educational hub tools are described. Civic education and its elements in the educational process of general secondary education are revealed and recommended for implementation. The analysis of the current state of implementation of educational hubs in the domestic educational practice is carried out, and the problems that need thorough research are revealed. The practical significance of the digital educational hub, as a component of the information-digital learning environment, is to promote the creation of innovations and their implementation in education; project implementation; professional and personal self-improvement, formation and development of the personality of a modern citizen who is active in the digital environment. The novelty of the study is based on the generalization of domestic and foreign experience; the recommendations are provided for the creation of a resource digital educational hub to support civic education.

Keywords: information and digital learning environment; information and communication technologies; civic education; digital educational hub; education in the Netherland; education in Belgium; education in Ukraine.

\section{REFERENCES (TRANSLATED AND TRANSLITERATED)}

[1]. The Cabinet of Ministers of Ukraine. (2018, Oct. 3). Decree No. 710-p, On Approving the Concept of of development of civic education in Ukraine. [Online]. Available: https://zakon.rada.gov.ua/laws/show/7102018-\%D1\%80\#n10. (in Ukrainian)

[2]. Ministry of Education and Science of Ukraine. (2019, March 27). Strategy for the development of civic education until 2022. Project. [Online]. Available: https://mon.gov.ua/ua/news/mon-proponuye-dlyagromadskogo-obgovorennya-strategiyu-rozvitku-gromadyanskoyi-osviti-na-period-do-2022-roku.

(in Ukrainian)

[3]. O.O. Hrytsenchuk, "Experimental verification of the effectiveness of the model of information and educational environment as a tool of developing civic competence of teachers", Computer at school and family, no.1. pp. 15-18, 2019. (in Ukrainian)

[4]. I.V. Ivaniuk, and O.V. Ovchruk, "Results of an online survey of teachers' needs for raising the level of professionalism in digital and ICT use during quarantine". Institute Information Technologies and Learning Tools of NAES of Ukraine, 2020. [Online]. Available: https://lib.iitta.gov.ua/719908/(in Ukrainian)

[5]. New Ukrainian School. Conception. [Online]. Available: http://mon.gov.ua/activity/education/zagalnaserednya/ua-sch-2016/. Accessed on: June 19, 2020. (in Ukrainian)

[6]. Communication strategy of the Ministry of Education and Science 2017-2020. (2017, May 26) № 4/1-15. [Online]. Available: https://mon.gov.ua/storage/app/media/komunikaczijna-strategiya-mon-20172020.pdf. (in Ukrainian)

[7]. V. Yu. Bykov, and V.H. Kremin, “ Categories space and environment: features of model representation and educational application", Theory and practice of social systems management: philosophy, psychology, pedagogy, sociology, no. 2, pp. 3-16, 2003. (in Ukrainian)

[8]. V. Yu. Bykov et al., Theoretical and methodological foundations of informatization of education and the practical implementation of information and communication technologies in the educational sector of Ukraine . Monograph. Kyiv, Ukraine: Comprint, 2019. (in Ukrainian)

[9]. V. Yu. Bykov et al., Formation of the informational and educational environment of students' lerning on the basis of electronic social networks technologies. Monograph, Kyiv, Ukraine: Pedagogichna dumka, 2018. (in Ukrainian)

[10]. Yu.O.Zhuk, "Personal pupil space in computer-oriented educational medium”, Information Technologies and Learning Tools, vol. 29, №3, 2012. [Online]. Available: http://journal.iitta.gov.ua/index.php/itlt/article/view/693/508. (in Ukrainian) 
[11]. A.M. Hurzhii, V. Lapinskyi, and L. Kartashova, Electronic educational resources as a social phenomenon, "Modern information technologies and innovation methodologies of education in professional training: methodology, theory, experience, problems", vol. 44, pp. 14-22, 2016. (in Ukrainian)

[12]. N.V. Morze, and S.M. Spivak, “Creating Modern Cloud-Oriented Personalized Education Environment Taking into Consideration Educational Process Participants' ICT Competencies ", Open educational eenvironment of a modern university, vol. 3, pp. 274-282, 2017. Doi: 10.28925/2414-0325. [Online]. Available: https://openedu.kubg.edu.ua/journal/index.php/openedu/article/view/92/125. (in Ukrainian)

[13]. O. V. Ovcharuk et al., Development of teachers' informational and communicational competence in the framework of the cloud-oriented learning environment: manual. Kyiv, Ukraine: Litera Ltd, 2019. (in Ukrainian)

[14]. A.V. Yatsyshyn et al., Digital transformation of open educational environments. Kyiv, Ukraine: DBA O.V. Yamchynskyi, 2019. (in Ukrainian)

[15]. P, Fisser, J. Voogt, J. Tondeur, and J. van Braak, "TPACK: kennis en vaardigheden voor ICTintegratie", Weten Wat Werkt en Waarom”, Kennisnet. Zoetermeer, vol. 2, no. 2, pp. 22-29, 2013. [Online]. Available: https://www.kennisnet.nl/app/uploads/kennisnet/publicatie/4w/4w_magazine_2013-2.pdf. (In Dutch)

[16]. O. Ovcharuk, I. Ivaniuk, N. Soroko, O. Gritsenchuk, and O. Kravchyna , "The use of digital learning tools in the teachers' professional activities to ensure sustainable development and democratization of education in European countries", in E3S Web of Conferences, 166 (10019), 2020. [Online]. Available: https://www.e3s-

conferences.org/articles/e3sconf/abs/2020/26/e3sconf_icsf2020_10019/e3sconf_icsf2020_10019.html. (In English)

[17]. I.I. Kapustian, "The development of learning computer aided environment si lifelong learning in Sweden", thesis, The Institute of Information Technologies and Learning Tools of NAES of Ukraine, Kyiv, 2012. [Online]. Available: https://lib.iitta.gov.ua/1086/. (in Ukrainian)

[18]. O.I. Lokshyna, "ICT-orientation of the school education curriculum in the countries of the European Union", Information Technologies and Learning Tools, vol. 45, no. 1, pp. 21-27, 2015. [Online]. Available: https://lib.iitta.gov.ua/714420/. (in Ukrainian)

[19]. I. V. Ivaniuk, "The development of computer-based learning environment in terms of the multicultural education of students in the European Union", thesis, The Institute of Information Technologies and Learning Tools of NAES of Ukraine, Kyiv, 2016. [Online]. Available: https://lib.iitta.gov.ua/166249/. (in Ukrainian).

[20]. O. V. Ovcharuk, "Current approaches to the development of digital competence of human and digital citizenship in European countries, Information Technologies and Learning Tools, vol.76, no.2, pp. 1-13, 2020. [Online]. Available: https://lib.iitta.gov.ua/720330/.(in Ukrainian).

[21]. S.H. Lytvynova, "National-patriotic education in project activities of students via cloud services and SCMOD”, Pedagogical journal Volyn, vol.8, no 1, pp. 72-82, 2018. Doi:10.29038/2415-8143. (in Ukrainian)

[22]. C. Birzéa et al. , All-European Study on Education for Democratic Citizenship Policies. Strasbourg, France: Council of Europe Publishing, 2004. [Online]. Available: https://rm.coe.int/16802f7040. (In English)

[23]. M. Ribble, G. Bailey, and T. Ross. "Digital Citizenship: Addressing Appropriate Technology Behavior", Learning \& Leading with Technology, vol. 32, no.1, pp. 6-9, Sep. 2004. [Online]. Available: https://eric.ed.gov/?id=EJ695788. (In English)

[24]. J. Bron, and E. van Vliet, "Democracy, participation and identity A curriculum proposal for Dutch education”, Teaching Citizenship, vol.34, pp. 32-35. 2012. [Online]. Available: https://issuu.com/openshaw/docs/actjournal34. (In English)

[25]. N.P. Bondar, L.O. Sharan, V.O. Hubenia, and I.S. Pidtilok, “ Implementation of innovative methods of work space organization in hotel industry ", Young Scientist, vol. 65, no. 1, pp. 423-427, 2019. doi: 10.32839/2304-5809/2019-1-65-98. (in Ukrainian)

[26]. O.S. Hrynkevych, and N.P. Lutchyn, "Analysis and modeling of processes of internationalization in higher education in the context of innovative development". Marketing and management of innovation, no. 3, pp. 314-325, 2017. doi: 10.21272/mmi.2017.3-29. (in Ukrainian)

[27]. S.S. Izbash, "Implementation of the principle of health care in the process of andragogical training of future teachers", in VII All-Ukrainian Scientific and Practical Conferenc. Pedagogy of Health, Chernihiv, Aprl. 7-8. 2017, vol.1, pp. 270-274. (in Ukrainian)

[28]. N.I. Klokar, "The basic (hub) school as the center of the educational cluster", in Current issues, problems and prospects for the development of humanitarian knowledge in the modern information space: national 
and international aspects: a collection of scientific papers, Eds. M.A. Zhurba, Montreal, Canada: CPM «ASF», 2018, pp. 63-65. (in Ukrainian)

[29]. L.I. Fedulova, "Innovative-technological HUBs are Drivers of Development of Regions", Economic theory and law: a collection of scientific papers, vol. 24, no.1, pp. 11-27, 2016. (in Ukrainian)

[30]. J. Knight, International Education Hubs: Student, Talent, Knowledge Models. Dordrecht, Netherlands: Springer Publishers, 2014. (In English)

[31]. D. Clandfield, "The School as Community Hub a Public Alternative to the Neo-Liberal Threat to Ontario Schools", Our Schools/Our Selves, Ottawa, Canada: vol.19, no. 4, issue 100, 2010, pp. 5-74. [Online]. Available:

https://www.policyalternatives.ca/sites/default/files/uploads/publications/ourselves/docs/OSOS_Summer1 0_Preview.pdf. (In English)

[32]. O.Ichilov, Patterns of Citizenship in a Changing World. In: O. Ichilov (ed.) Citizenship and Citizenship Education in a Changing World, The Woburn Press, London, 1998, pp.11-27. (In English)

[33]. V.P. Verbytska, "Theoretical and methodical foundations of civil education of youth in secondary schools", doctoral diss., Institute of Problems on Education NAES of Ukraine, 2010. (in Ukrainian)

[34]. O. Pometun, T. Remeh, and L. Pylypchatina, Science of law. Practical course: methodical manual for teachers. Kyiv, Ukraine: Logos, 2009. (in Ukrainian)

[35]. I.H. Taranenko, "Democratic values in becoming a citizen", Pedagogy and psychology, no. 2, pp. 28-35, 1997. (in Ukrainian)

[36]. S. Holovko (Ed.), Ukrainian pedagogical dictionary, Ukraine: Lybid, 1997. (in Ukrainian)

[37]. Functioning of support schools based on the results of the survey of principals of support schools. Institute of Educational Analytics, Ministry of Education and Science of Ukraine, 2017 p. [Online]. Available: https://iea.gov.ua/wp-content/uploads/2017/12/1.pdf . (in Ukrainian)

\section{$(\mathrm{Cc}) \mathrm{EY-NC-SA}$}

This work is licensed under Creative Commons Attribution-NonCommercial-ShareAlike 4.0 International License. 